http://dx.doi.org/10.12775/szhf.2019.034

PaWę Sikora

Maria Curie-SkŁodowska University, Lublin

E-MAIL: PAWEL.SIKORA@POCZTA.UMCS.LUBLIN.PL

ORCID: 0000-0001-7960-0786

\title{
Sensationism and the Problem of Perceptual Content. The Case of Condillac
}

\section{Introduction}

The empirical perspective of Condillac's philosophy seems to be posing quite a difficult task for itself. First, it looks for an epistemological arché and wants to define the limits of human cognition and, secondly, it seeks to explain the complex process of acquiring knowledge: from perception to the form of concepts and linguistic expressions. The latter, which emphasizes the aspect of linking sense experience with signs, is not only an attempt to rehabilitate the sense experience "after Descartes" in the French Enlightenment, but also results from the discussion and criticism of Locke's philosophy. Another element that emerges from Condillac's position is the problem of the status of the rules of linking sense content with thinking and judgments. This issue concerns conceptually or only psychologically defined rules and is now being discussed vividly in the contemporary analytical philosophy of perception. 
The ambitious and broadly defined scope of philosophy pursued by Condillac is also - despite the declared reluctance to metaphysical theses - a proposal that outlines a certain pre-epistemic structure on which a cognitive relation is based. Sensationism and phenomenalism of the author of the Treatise on Sensations entails strictly metaphysical assumptions regarding the very existence of reality, hidden under the stream of impressions. However, despite the impossibility of making clear decisions about the nature of this reality ${ }^{1}$, the sphere inaccessible to cognition, hidden under a set of sense data, is something that to some extent allows for "anchoring" these data in the external world and thus enables Condillac to justify his position with common sense. Thanks to a broader perspective, which also includes some metaphysical presuppositions, I believe that Condillac's proposal can be seen in a slightly different, more contemporary light and not only as a historically distant theoretical proposal.

This article does not claim to be a historical analysis of the nuances of the development of his thought - I am aware not only of the complexity of his position, but also of the attempts to shift many accents ${ }^{2}$. I am also aware of the differences between his early writings and the main work, the Treatise on Sensations. I just want to highlight a number of theoretical problems that the sensationism in Condillac's version entails and stress that the main problem in the field of sensationism will be to determine the status of knowledge on the basis of sensations only. The consolidation of this knowledge (which is the essence of the empirical perspective) seems to be even impossible on the grounds of radical sensationism and is also troublesome for the "other side" of Condillac's position - his phenomenalism.

Undoubtedly, despite the distance to the Cartesian tradition, Condillac remains in the paradigm of the subjective definition of the foundations of knowledge and at the same time reduces all cognitive activity to a form that

1 Cf. Etienne B. Condillac, Cours d'étude pour l'instruction du prince de Parme, vol. IV (Parme 1775), 124-125, retrieved from: https:/gallica.bnf.fr/ark:/12148/bpt6k42635k/f143. image.

2 A separate, excellent study is devoted to this subject: Marek Gregorowicz, Tematyka sensualistycznego uzasadnienia tożsamości podmiotu ludzkiego i jego odniesień do realności w twórczości Condillaca: dwa studia badawcze (Łódź: Wyd. Uniwersytetu Łódzkiego, 1993). 
is only empirical. Both sensations and activities are the material of knowledge $^{3}$, but at the same time the chronology of the process of its formation as Condillac repeatedly suggests - seems to indicate a certain distinctness of moments of experience and intellectual operations. This issue, which accompanies the famous experiment with the statue, concerns the overall structure of sense-knowledge, its complexity and seems to fit well into today's dispute about the conceptual or non-conceptual nature of the perceptual content ${ }^{4}$. This dispute, which is worth noting, appears in modern thought with the Cartesian breakthrough and the reactions to it in British empiricism in the $17^{\text {th }}$ and $18^{\text {th }}$ centuries, and only then does it echo in Kant's philosophy. Therefore, it does not have only a contemporary background and does not begin with the emergence of transcendental reflection. In other words, if the proponents of the conceptual character of what is given in perception are right, they can seek inspiration not only from Kant or Hegel, but also from Condillac. Then, however, the thought of the author of Essay should be expressed in a slightly different light.

\section{The Structure of the Sense Experience}

Referring to Locke and criticizing him at the same time, Condillac tries to radicalize the genetic empiricism of the author of Essay Concerning Human Understanding, recognizing that all elements of knowledge come from the senses, and thus, Locke's activities of inner experience (reflections) do not have full autonomy, but directly result from experiencing sensations. In the

${ }^{3}$ Cf. Etienne B. Condillac, L'Essai sur l'origine des connoissances humaines (Amsterdam 1746), 3-4, further quotations retrieved from: https://gallica.bnf.fr/ark:/12148/btv1b8626251z/ f35.image.r=L'\%20Essai\%20sur\%20l'origine\%20des\%20connoissances\%20humaines.

${ }^{4}$ It is mainly about the discussion about W. Sellars' "myth of the given", J. McDowell's conceptualism and reactions and comments on these positions - a discussion that has been dominating the dispute over the nature of perceptual content for over two decades. Cf. e.g.: Wilfrid Sellars, "Empiricism and the Philosophy of Mind", in: Minnesota Studies in the Philosophy of Science, vol. I (Minneapolis: University of Minnesota Press, 1957); John McDowell, Mind and World. With a New Introduction (Cambridge, Mass.: Harvard University Press, 1996); Bill Brewer, Perception and Reason (Oxford: Oxford University Press, 1999). 
Essay on the Origin of Human Knowledge and the later Logic, understanding takes place on the basis of experience, all quantitative determinacies are contained in perceptions, and clarity itself refers to experience ${ }^{5}$. In the Treatise, in turn, radical sensationism was to completely reduce the activity of the mind to experience sensations; thus, the concept of sensation gained a wide reach, combining the intellectual components of perception with the experience itself ${ }^{6}$. This makes it easy to see that Condillac's sensationism weakens itself, in a way, by suggesting the need for conscious mind activities closely related to experiencing sensations.

Therefore, for the declarative program of sensationism, it is also problematic that Condillac, while distinguishing the components of experience, suggests that obtaining impressions and the sensations themselves, in order to be perception, also require the presence of the object ${ }^{7}$ and reference thereto ${ }^{8}$. On the one hand, it gives him the opportunity to avoid the accusation of idealism, and on the other hand, this attempt to turn to objects gives him a chance to consider experience as the best guarantee of contact and knowledge about the actual reality. The last, key element is the possibility of making judgements "that what we refer to things really belongs to them" . Condillac's sensationism and phenomenalism turns out to be a theory of experience, which, although distancing itself from metaphysical considerations about objects as such (substances) outside the context of experience, at the same time seems to be a position recognizing a certain element of epistemological realism, provided we consider our perceptions to be real objects of experience and relate them to objects outside of us. Another accompanying aspect is the emphasis on the proto-conceptual activity of the subject, who on the basis of the experienced content makes a relational reference to the extra-empirical rules that underlie empirical knowledge.

5 Cf. Condillac, L'Essai..., 14.

6 This aspect is particularly emphasized by: James H. Stam, Condillac's Epistemolinguistic Question, in: Psychology of Language and Thought. Essays on the Theory and History of Psycholinguistics, ed. R. W. Rieber (New York: Plenum Press, 1980), 81.

7 Cf. Condillac, L'Essai..., 170,

8 Cf. ibidem, 15.

9 Ibidem, 15. 
The key question will therefore be the problem of "referencing" and whether it is of the nature contained in the act of perception itself, or is merely a sensory-derived intellectual operation. The act of reference has two instances in Condillac, it is a relation of:

a) sensations to the object;

b) judgement to the object ${ }^{10}$.

While in the case of the latter there may be a danger of making a mistake, the first relation is quite troublesome, too, because despite the reference to the object we are not sure whether the sensation " $\mathrm{x}$ " is adequate (or similar) to the property " $x$ " of the object itself. The experience itself seems to be certain and clear, but only in the sense of subjective possession of some sensation, some sensory quality of something. However, the judgments in which we decide about the nature of objects on the basis of sensations may be false, as long as we attribute to them something that belongs only to our sensations. However, in order to avoid this error, one should only limit oneself to the analysis of internal states, without the above mentioned reference - however, the reference itself causes the necessity to modify certain assumptions, which are the basis of Condillac's position.

Thus, there appears the basic problem of empirical phenomenalism: on the one hand, this position wants to remain empirically oriented towards the object sphere, distancing itself from possible metaphysical speculations, and on the other hand, the reference to objects itself is difficult because of the limited access to sensations only, i.e. to internal phenomena (impressions). Of course, the attempt to avoid this problem - which appeared with full force already in Locke's case - indicates the necessity of using the construct of "reference", but it must entail a significant modification of either the position of phenomenalism or empirical directing towards external reality ${ }^{11}$. Therefore, not so much the problem of the sensory defined process of cognition, but rather the reference of sensations to the object and the role of the

10 Cf. ibidem.

11 An interesting analysis of this issue is presented by Falkenstein, who poses the problem of the relationship between the sensory content of the mind and the quantitative (primary) qualities reserved for external objects - cf. Lorne Falkenstein, "Condillac's Paradox", in: Journal of the History of Philosophy 43, No. 4 (2005): 403-435. 
distinguishing reflection and language ${ }^{12}$ seem to be an important issue which allows us to understand the complexity of the Condillac's standpoint. It is all the more important because Condillac himself points out that perception is in fact an operation of understanding, while the experience itself is not completely isolated from reflection, although at the same time and already from the level of thinking about the process of cognition it distinguishes perception from perceiving consciousness ${ }^{13}$.

This distinction, however, seems to be helpful only in analyzing the structure of sensory experience, but it is not the same as a real separation of two actions in perception. In other words, the basic cognitive activity has a reflexive character: it is perception and perceptual consciousness ${ }^{14}$. If so, Condillac declares something different from what follows from his deliberations - for the essence of sensationism is to explain that all cognitive activities of the subject result from experiencing sensations themselves. Here, however, it turns out that experiencing consciousness and what is experienced occur simultaneously at the very beginning of acquiring knowledge. The resulting conclusion can be as follows: Condillac criticizes Locke for isolating the inner experience, but at the same time he "replaces" this experience with his own version of "consciousness perception" or even "reflective perception"15.

In the Treatise on the Sensations, in turn, Condillac (after Diderot's criticism and his accusations of idealism) shifts some accents and emphasizes the strictly sensationalist aspect of his proposal. He declares that intellectual and linguistic activities are equivalents of perception itself, so that the basic activities of the subject function not only as correlated or parallel to perception, but are forms of perception itself.

12 The role of a language as a medium between perception and reflection is discussed in more detail by: Ellen McNiven Hine, A Critical Study of Condillac's Traite des Systems (Hague: Martinus Nijhoff Publishers, 1979), 206-207.

13 Cf. Condillac, L'Essai..., 24-27.

14 Cf. Udo Thiel, "Self and Sensibility: From Locke to Condillac and Rousseau", Intellectual History Review, 25, No. 3 (2015): 260; cf. also: Gregorowicz, Tematyka sensualistycznego uzasadnienia..., 29.

15 O'Neal even writes that Condillac in Essay... compares experience and reflection as a way of understanding or treats reflection as a form of perceiving according to the criterion of truth - cf. John C. O'Neal, The Authority of Experience. Sensationist Theory in the French Enlightenment (University Park: Penn. State University Press, 1996), 18. 
And this is where I believe the key problems arise: the issue of attention and memory. On the one hand, these activities do not belong to passive experience; on the other hand, they are reduced to the equivalent of sensory content. Therefore, if they are a manifestation of the perceiver's activity, a state of conscious perception of sensations, it allows for a brief formulation of Condillac's position as a quasi-conceptualist position, where we do not have a network of notions accompanying perception, but at the same time sensory experience is not free from the necessary activity of the subject (especially his attention), going beyond the mere experience of impressions. On the one hand, the experience of the impression of something takes place "from the presence of the objects" which causes it, and the conscious experience is intentional because it is a testimony to the presence of some kind of impression ${ }^{16}$. On the other hand, however, the experience itself evolves and in the process of acquiring knowledge it becomes an intellectual activity which, interestingly enough, is preceded by attention and a positive or negative reaction to stimuli. Condillac reduces the role of attention ${ }^{17}$, in turn, to the experience of some simple content, in this very moment of experience. However, if it turns out that it is possible to reduce all the powers behind the experience to a single sense, then it turns out that certain individual minima sensibilia are not only concrete contents of the sensory experience (sensation of red and/or pleasant smell), but also properties of objects (smell of a rose or a violet) ${ }^{18}$. This may mean that Condillac either attributes to the statue the ability to recognize things beyond the senses and not the fragrance qualities themselves or, for example, links a fragrance to an external object by means

16 Cf. Condillac, L'Essai..., 41.

17 Nichols compares Condillac and Reid's standpoints, emphasizes the fact that sensations belong to the mind and the moment of pleasure and pain, as a primordial factor for the development of sense knowledge and confidence in the reality of the outside world - cf. Ryan Nichols, Thomas Reid's Theory of Perception (Oxford: Oxford University Press, 2007), 98-99. If this is key, then there is an obvious recognition of the perceptual consciousness as primal in the face of sensations and its content - this recognition (again) does not result at all from the sensationism, which defines the mind and its activities as originating from sensations, or reduced to them.

${ }_{18}$ Cf. Condillac, Traité des sensations, vol. 1 (Londre-Paris 1754), 18, further quotations retrieved from: https://gallica.bnf.fr/ark:/12148/btv1b8626258v/f30.double.r=Condillac, $\% 20$ \%C3\%89tienne\%20Bonnot\%20de. 
of a reference act. Both possible solutions undermine Condillac's sensationism to a large extent, because it turns out that the subject-statute does not limit itself to capturing the sensations themselves and constructing knowledge only on their basis, but shows - contrary to declarations - internal, extra-sensory activity.

Another contentious issue that goes beyond the ability to capture the elementary content of perception is the above-mentioned role of attention. First, if one treats attention as an intentional orientation towards sense content, this ability is not something that appears as a result of empirical influence only. It is a subjective activity that encounters sense content, but does not result from it, i.e. does not appear merely as a product of developing empirical knowledge. Secondly, attention is reduced to focusing on pleasant or unpleasant sensations. It is easy to notice, however, that attention and memory appear in Condillac as the equivalent of the non-empirical procedure of recognizing what is nice and unpleasant to the statue. This procedure does not contain a perceptual content, but is a subjective reaction to it, or, in other words, a basic activity that encounters empirical content, but is not reduced to it. This is important because without it the process of knowledge formation could not be recreated, but at the same time it is not something that could be considered minima sensibilia. Therefore, if Condillac stands for sensationism, it is moderate sensationism (not to say weak), defined by certain rules that direct a marble statue to acquire more and more complex elements of knowledge. It must possess these rules a priori, because otherwise they could not appear as a result of the empirical interaction only. In other words, the nonempirical actions of the perceiving subject are correlated with sensations, but do not emerge from them because their status is completely different. The passively accepted perceptual content is not the only basis of sensory knowledge, but requires operations on these contents - operations of a completely different character than just the reception of qualitative perceptual content.

The problem seems to be that Condillac, while criticizing the nativism of the Cartesian school and at the same time distancing himself from the Locke's concept of internal experience, does not notice that the marble subject does not contain any ideas (conceptual knowledge), but must contain pre-conceptual rules defining the procedures of thinking. A good illustration is an example with the occurrence of pain - the subject knows nothing, 
because he feels only one kind of experience: it is pain itself. Attention directing the statue towards this one experience (i.e. an activity) is indeed preceded by a distinction between suffering and pleasure, but when the pleasant experience appears, not only memory, but also the distinction between both states and the desire for what is pleasant is revealed ${ }^{19}$. In this example, although there is no reference to the object mentioned above (that something causes pain), on the other hand, its ability to react to the difference between the remembered unpleasant experience and comparing it to the desired experience (pleasure) are not purely empirical operations, defined and reduced to sensory qualities. The very function of attention ceases to be reduced to the reference to one experience only but is also noticing the difference in qualitatively different states. In other words, attention and memory are prerequisites for the formation of knowledge on the basis of the experienced pleasures and sorrows, but the necessary rule is to compare and notice the difference between the two states.

The concept of difference itself can be constituted and realized later, with a set of ideas separated from the empirical material, but the distinction itself must be used as a non-empirical rule underlying perception. Recognizing the difference between a pleasant and an unpleasant state is not related to empirical content, nor is it an intellectual addition to impressions in the form of a well-defined, rational pattern. An intermediate solution would be to assume that there are some pre-conceptual procedures for the creation of knowledge, which do not result from the sensory content itself, but at the same time are not inherent and ready-made concepts. Operations of this type can be understood as a manifestation of necessary, non-empirical activity. This of course undermines the status of the Condillac's statue as a subject equipped with only one and only passive ability to perceive sensations, although on the other hand - not clinging to the letter of Condillac's argument - it allows the knowledge to "take off" and give momentum to the process of cognition. In my opinion, therefore, either we are dealing with inconsistent sensationism in Condillac's work or the construction of a subject limited to one sense will be doomed to a certain epistemological impasse. If we are faced with the process of acquiring empirical knowledge, then the

19 Cf. Condillac, Traité des sensations, 22-24. 
activity of the perceiving consciousness is governed by certain rules, which cannot be reduced to experiencing content (sweets, red, etc.), because this activity alone cannot appear as a result of the accumulation of such content. In other words, Condillac shows not so much that the original intellectual activities are the result of qualitative sensations, but rather that these activities are revealed with perception and that the sensory knowledge from perception can only be meaningful if the basic thought processes are already present in the act of perception.

\section{Perceiving Consciousness}

In my opinion, it can be noted that regardless of the declared radicalization of Condillac's position in the Treatise on Sensations in relation to his earlier work (Essay on the Origin of Human Knowledge), it is clearly visible that the thesis on the sameness of consciousness and perception ${ }^{20}$ is crucial for explaining the sources of knowledge and allows us to indicate not only that perceptions are reflexive: they are sensations and at the same time are consciousness of sensations, but also that consciousness is not a second-rate activity resulting from perception. It is this activity - as Condillac writes that is the basis of our experience ${ }^{21}$. If so, it is something that must go beyond the strictly perceptual content, but at the same time gives it a meaningful use. Without this second element, the passive experiencing and reducing our knowledge only to its sensory source will not let us start the process of constructing cognition at all. Therefore, we can talk about the perceptual consciousness in the following way:

1. At the first level, it is referred to the experiencing itself, passive reception of impressions. It is then a state of conviction that I am now experiencing such and such content. It will be the consciousness of presence of the very perception of something and it would boil down to the state of quasi-knowledge: I am now experiencing sweetness - this state could

20 Cf. idem, L'Essai..., 37.

${ }^{21}$ Ibidem, 41. 
be explained only by sensationism, but with the necessary acknowledgement of a certain non-empirical activity, which is a quasi-reflection on the very fact of experiencing something. This activity, however, is not of a superior character, because it does not reveal itself above and beyond the sensations themselves, but it is above all a proto-knowledge, relating to the acknowledgement of the very presence of something that is experienced. Therefore, this level speaks only of phenomenal being of something that is perceptible.

2. At the second level, consciousness seems to be a reference to the necessary presence of the physical object (thing) itself, which causes an experience of e.g. sweetness. At this point, our basic reference activity also shows a certain non-empirical vector, because it seeks the meaningfulness of experiencing sweetness in the real and objective sphere. And while the first level connects the content with the state of the belief that some experience is simply taking place, the second level connects sensationism in epistemology with the real correlate. However, regardless of the problems and limitations of establishing the ontological structure of this correlate, it is at the same time the thing towards which consciousness is directed that is only a phenomenon, as the only reality to which it can refer. In other words, the consciousness of the experience of red (at the first level) must be accompanied by the presence of the consciousness of an external object, thus going beyond the perception of the content. This level therefore speaks of a necessary recognition of the external and no longer only phenomenal reality to which the perceiving consciousness refers;

3. At the third level, the experiencing consciousness is a pre-conceptual activity of paying attention, memory, discriminating and comparing. It cannot be separated from the concrete manifestations of its activity, and since it acts only in relation to the empirical, the same contents are linked in relation to the activity of noticing, distinguishing and consequently recognizing that the experience of $\mathrm{x}$ is different from the experience of $y$ and can relate to another external object. The above issue is particularly visible when the consequences of the subsequent sensations are discovered - referring to them, distinguishing and especially comparing them is the basis for making judgments. This means that 
Condillac identifies judgement with the recognition of difference and deciding that, for example, the experience of red is different from sweetness. At this level, consciousness is an activity related to what is given in various relationships.

The juxtaposition of the above levels enables to distinguish the active status of the perceiving subject, which - regardless of the strictly experiential basis - is not only to extract knowledge on the basis of what is only sensory, but its activity is also the basis of the whole process.

Impressions as a material of knowledge are the correlate of the necessary activity which is perception - but it is easy to notice that perception is already an activity and necessarily an activity aware that something is given as an impression (pleasant or unpleasant). In this sense, sensationism proclaiming that all mind activities are the result of perception, turns out to be contradictory. The perception itself as an action must be a correlate of its content and must therefore be an activity that immediately encounters all sensory data. Of course, one can easily reject this criticism and point out that perception is not an activity, but a mere ability to accept the imprinting (imprimer) impressions. This, however, is troublesome for Condillac because of the aforementioned role of attention, as the consciousness that I am experiencing something. It is all the more emphasized when Condillac in his Logic indicates that attention is in fact a primary distinguishing activity and is the same as experiencing ${ }^{22}$; whereas comparison is a double attention ${ }^{23}$ - that is, double differentiation, and thus also double experiencing. Condillac's sensationism is not radical in fact, because it does not consist in justifying that the activities of the mind result from experiencing impressions and only the experience of impressions creates more and more complex activities. Sensationism that can be defended in this respect is moderate sensationism which is in fact a position emphasizing the proto-conceptual nature of sense impressions that are strongly connected with the activity of the subject.

By linking perception to the aforementioned that I am perceiving something, all perceptions are clear and obvious, as well as given from the external,

22 Cf. Etienne B. Condillac, La logique, ou Les premiers développements de l'art de penser, (Paris 1780), 48-50, further quotations retrieved from: https://gallica.bnf.fr/ark:/12148/ bpt6k80138k/f55.double.r=La\%20logique\%20et\%20le\%20trait\%C3\%A9\%20des\%20animaux.

${ }^{23}$ Cf. ibidem, 50. 
real world at the same time. It results from (equally troublesome) concept of the passivity of perceptions - if a statue receives content in an apparently passive way, then any impressions are not its product. However, in an obvious way, the recognition of the basic activity operating on the side of the subject (the aforementioned that I am experiencing something) does not negate the reality of any content at all. The latter are only a necessary correlate of the perceptual, active consciousness of the subject. In this way sensationism would be connected with strong epistemological realism, but in order to be a test of sense knowledge it cannot be radical sensationism.

The essence of the issue described above is presented in the work by Grygorowicz in a slightly different way. In his opinion, perception is the realization of reality; there is no division into a subject and an object for the perception of impressions. Perception is experiencing itself and nothing else. A perception, in turn, is already a conscious, continuous realization of the duration of perceptual activities - owing to which we are aware of the difference and the subject-objective relation ${ }^{24}$. In my opinion, if Grygorowicz is right, then experiencing the content is not perception, because this requires a conscious act that some content is given. Moreover, the key element of the emergence of a conscious perception from passive experience of impressions will be time. The time relation that must exist between the imprint of the content and the conscious perception indicates that the non-empirical conditions of perception are not only present in perception, but are even its constitutive moments. The presence of time in perception clearly indicates that Condillac's thought is a predecessor of transcendental philosophy ${ }^{25}$. On

24 Cf. Gregorowicz, Tematyka sensualistycznego uzasadnienia..., 38-39.

25 An interesting and frequently commented upon text is the article by: Melvin W. Beal, "Condillac as Precursor of Kant", in: Studies on Voltaire and the Eighteenth Century, No. 102, ed. T. Besterman (1973): 193-229. The author does not elaborate on the problem of time in the process of perception in Condillac, but comparing his position with Kant, he emphasizes that both of them, distinguishing perception from thinking, point to the necessary presence of judgments as a manifestation of thinking (205-206), which - as essential - is revealed in Condillac's writings through the element of attaching signs to perception (212), and thus stresses the presence of a non-empirical component in the process of perception (214). Although Beal repeatedly notes the differences between perception and thinking in Condillac and Kant, both activities require an intermediate element. And while according to Beal Condillac does not recognize such an element (229), in my opinion, it is precisely the attention to 
the other hand, if the original form of perception is to become a conscious perception, Condillac, in a sense, "glues" the sensory component itself to the necessary activity of the subject for the sensation to become a conscious perception. Otherwise, some "adjusting" rule would have to appear between the sensation and the perception. This "gluing" would in turn result in either the time relationship disappearing, or what is a passive experience being simultaneously an active perception. In the case of both solutions, the thesis of protoconceptual, necessary activity, underlying perception would be justified, because the original moment of experience is not separated from attention ${ }^{26}$; perception is at the same time consciousness directed at its correlate, since already at the first sensation the statue focuses on stimulation ${ }^{27}$.

\section{The Content of Perception}

On the basis of the above statements and the previously identified levels of perceiving consciousness, it is possible to determine the elementary component of the perception that Condillac traditionally calls "simple ideas". They are the basis for empirical reference, but they do not appear above or beyond the operations of producing complex ideas, i.e. certain rules that Condillac calls "penetration, discernment, sagacity"28 - but they appear as derivatives of the act of perceptions. Therefore, complex ideas do not arise as a result of an accidental juxtaposition of these simple ideas, or as a result of a mere enumeration of memorized simple ideas. Simple ideas may form the basis of complex ideas, i.e. ultimately concepts, provided their construction is the result of the activity called by Condillac an experience réfléchie ${ }^{29}$.

the perceptual content that is at the same time the manifestation of the necessary rules that constitute the sense knowledge and defines the very content of perception.

${ }^{26}$ Similar doubts are raised in the text by: Suzanne Roos, "Consciousness and the Linguistic in Condillac", MLN 114, No. 4 (1999): 680.

27 Cf. Condillac, Traité des sensations, 20.

${ }^{28}$ Cf. idem, L'Essai..., 157-158.

29 Ibidem, 166. 
The question that must appear in this respect concerns the possibility of grasping a simple idea and pointing it out as an empirical example of existence for consciousness, outside the context of attention or the application of the knowledge-creating rules. In my opinion, both the characteristics of the perceiving consciousness, vector-oriented to empirical correlates, as well as the very status of attention and the ability to use names in the examples employed by Condillac clearly demonstrate the related structure of perception, where simple, purely experiential elements (e.g. the perception of red) are linked to each other by a series of reference rules - or in other words - the necessary relationships which bind together not only empirical knowledge on the basis of the perception itself, but are the foundation of the very process of perceiving something. This would mean that Condillac's declared sensationism is immediately weakened by his own analysis of the perception process, from which it is impossible to completely eliminate the element of reflection, which, as he himself stresses, is "the power of directing our own attention" 30 . The latter must accompany all perceptions since it is the basis for recognizing the presence of the experience itself (the first level of the perceiving consciousness), as well as the presence of the external object (the second level of the perceiving consciousness).

Another problem arises when Condillac, in his early deliberations (in Essai...), seems to be evasive, wishing to explain the relationship between attention, imagination, memory and reflection. In his opinion, the source of associating ideas is attention ${ }^{31}$, and it is also the source of imagination and memory. Attention, together with imagination and memory, produces an act of reflection. The latter is at the same time "power of directing our own attention", which in turn manifests itself in concrete knowledge-creating activities: distinguishing, abstracting, comparing, and assembling ideas ${ }^{32}$. These mutual relationship can be presented in the following way:

Attention $\rightarrow$ Associating, as well as Imagination and Memory $\rightarrow$

Reflection $\rightarrow$ Differentiating/Abstracting/Comparing/Assembling

\footnotetext{
${ }^{30}$ Cf. ibidem, 88.

31 Cf. ibidem, 55-56.

32 Cf. ibidem, 88-93.
} 
It is easy to notice that actions of a reflective nature related to concrete experiences must already be present in the act of associating ideas, because it does not consist in a chaotic juxtaposition of ideas, but in juxtaposing them according to some rules. Radicalization of the position, defined in the Treatise... and emphasizing that all activities of a reflective nature (Locke's internal experience) result only from experiencing some kind of one type of sensation, does not dispel the above doubts, either. In the Treatise Condillac tries to specify his theses and by defining the terms he indicates that attention is directed to some particular sensation and the way of revealing this attention consists in comparing and judging itself ${ }^{33}$. The effect of these activities is reflection, that is, the ability to perceive the "reflexive attention" in relation to the experience of red, sweetness, etc. This process, in turn, can be described as follows:

\section{Attention $\rightarrow$ Comparing and Judging $\rightarrow$ Reflection}

Attention in both schemes is the beginning of the process of empirical cognition, and reflection is its culmination. In the sphere of declarations, it looks clear and quite consistent - the reflection as a result of the process of experiencing sensations fits perfectly into the project of sensationism. However, it is easy to point out the lack of consequence here, consisting in the recognition that attention at its roots accompanies experiencing sensations and fulfils the role of reflection activity which Locke distinguished in the form of internal experience, and which Condillac wanted to reduce to perception itself. If, on the one hand, attention is identified with an impression referring to one object (the experience of redness or sweetness), then it is already a separating activity which is not only the experience of the impression. Attention seems to be rather a necessary reference of the perceiver to the experienced content because thanks to it we can talk about the active character of the perception process directed at its object (the content of the experience or an external object), as well as the very transformation of attention into its subsequent forms. However, if one were to accept, as the author of the Treatise, that the

${ }^{33}$ Cf. Condillac, Extrait raisonné du traité des sensations, in: Oeuvres philosophiques de l'abbé de Condillac (Parma 1792), 388 and 389-390, quotations retrieved from: https://www.erara.ch/zut/content/pageview/8119155. 
activity of comparing and judging as components of reflection are revealed only when attention is directed at two objects, and the primary, supposedly inactive, non-reflective and purely experiential moment of perception takes place at the moment of perceiving one or more influential content, this attention without the background for reflection (distinguishing, abstracting, comparing, judging) would not be able to "know" what one content, stronger and separated from a number of other contents of the experience is. The very fact that attention is guided by such non-empirical characteristics of impressions proves that it cannot be at its source only the impression itself, but also a recognizing activity owing to the functioning of non-perceptual elements of perception.

Noticing this shortcoming results in Condillac seeming to replace the Locke's internal experience with an activity of attention and giving it a larger scope of activity than declared from the perspective of his sensationism. Moreover, on the one hand, he seems to separate the experience of sensations as a primal moment of perception, free from other activities, and on the other hand, he identifies it with attention as modified experience which already works in its very foundations and is not reduced to a passive acceptance of simple ideas. His formulation that sensation devient attention ${ }^{34}$ results from confusing the levels of perception - passive with active - and consequently, he confuses the activity of attention with the correlate of this activity. The source of this misunderstanding is perhaps the fact that he defines attention as a reference to only one experience and, therefore, it must be focused only on this very content which is given at the moment. But then, without using other activities, the whole process of acquiring knowledge would get stuck in the experience of this one sensory quality. However, if the analysis of empirical sources of knowledge is to indicate at the same time the whole process of learning the statue, then the acquired sensory experience must have its internal correlate in the form of operations of the subject (referencing, comparing, distinguishing, etc.).

${ }^{34}$ Cf. ibidem, 388. 


\section{Conclusions}

The analysis of Condillac's position shows that his declared, radical sensationism is extremely hard to maintain, if at all possible $e^{35}$ :

(a) Condillac is unsatisfactorily justifying the existence of acts by the subject resulting from passive perception of the content;

b) radical sensationism, ignoring the need to apply subjective rules at the very moment of experiencing content, contradicts the thesis of the nature of empiricism based on creating knowledge;

c) in the Treatise, by subordinating all activity of the subject to the impressions, Condillac suggests that they themselves become organizing and reflexive forms, thus taking over the role of the activity of the mind if the Treatise was to be the banner of radical sensationism, then Condillac involuntarily takes the position of proclaiming the existence of the quasi-conceptual content of perception;

d) explaining and reducing the role of attention to specific intellectual activities indicates rather the necessary, non-empirical activity of the subject accompanying the experience;

e) Condillac's sensationism cannot be combined with phenomenalism, according to which the objects of our perceptions are complexes of sensations the connection of which requires non-empirical procedures based on perceptual content, but not reduced to it.

Despite the thesis about the uselessness of abstract systems, Condillac's concept lies in the perspective of metaphysical thinking ${ }^{36}$. Contrary to the spirit of the French Enlightenment, it is a continuation of the disputes over

35 While W. Wojciechowska claims, then, that Condillac was not a pure and consistent sensationist - cf. Wanda Wojciechowska, "Sensualizm Condillaca", in: Szkice filozoficzne: Romanowi Ingardenowi $w$ darze, ed. Z. Żarnecka (Kraków: PWN, 1964), 188 - in my opinion, Condillac's attempts to do so show (contrary to his intentions) that radical sensationism is virtually impossible. Regardless of the differences in understanding the status of impressions and the process of perception described in the Essay on the Origin... and in the Treatise..., it is in both of Condillac's key texts that the presence of an active, non-impressionist (noncontentual) and subject-derived aspect of the knowledge-creating perception is clearly visible.

${ }^{36}$ More on the subject by: Stanisław Janeczek, "Przejawy refleksji metafizycznej w filozofii Etienne’a Bennota de Condillaca (1715-1780)”, in: Z dziejów filozoficznej refleksji nad 
the possibility of justifying knowledge on the basis of perception - not only because Condillac seems to be discussing rather with Locke or Berkeley, but mainly because, despite the declarations, his thought is ultimately involuntarily entangled in the question of subjective conditions of perception. And this is not at all its weakness; on the contrary - the whole complexity of our perception indicates at the same time the necessary intellectual activity, somehow "compressed" with our perception ${ }^{37}$. This allows us to understand Condillac's thought as a certain anticipation of transcendental philosophy. Another side of this problem is the consequence of Condillac's sensationism, his phenomenalism: things are complexes of our perceptions, but even our perceptions are complexes of individual impressions. In my opinion, the consequence of such a double reduction would be a situation where the existence of sense knowledge would be very difficult. The necessary activity of the subject, present in the perception, makes this reduction impossible because it fulfils a constructive role: the structure of experience is simultaneously filled with real empirical content, as well as with subject-derived organizing rules ${ }^{38}$.

The metaphysics of objectivity transformed after Descartes into the metaphysics of subjectivity in Condillac's writings becomes an unintentional metaphysics of experience - because it is a speculative analysis of the process of cognition in relation to the genesis, process, and object of perception. Thus,

człowiekiem. Księga pamiątkowa ku czci Profesora Jana Czerkawskiego (1939-2007), ed. P. Gutowski, P. Gut (Lublin: Wyd. KUL, 2007), 257-274.

${ }^{37}$ Intellectuality is, according to Chudy, one of the key, subject-derived moments of perception. Cf. Wojciech Chudy, "Percepcja a pojęciowanie i sądzenie", Roczniki Filozoficzne 28, No. 1 (1980): 262.

${ }^{38}$ In contemporary research in the field of analytical philosophy of experience, phenomenalism is presented as a position that must use the thesis of objects of perception as "bunches" of certain elementary sense properties (quale). This understanding of phenomenalism is usually presented as the bundle theory of the object of perception, which in turn often receives support from the trope theory. According to this theory, we perceive not so much things, but always individual properties, which in different things are only similar - cf. Edward J. Lowe, "Tropes and Perception", in: Tropes, Universals, and the Philosophy of Mind-Essays at the Boundary of Ontology and Philosophical Psychology, ed. S. Gozzano, F. Orilia (Heusenstamm: Ontos Verlag, 2008), 175-192. If one were to assume that things are essentially related tropes, the general aspects contained in things would be the result of the conceptual link that the subject makes. 
the metaphysical reflection directs its vector back to objectivity, though with the subjective perspective already taken into account. Notwithstanding the critics of his thoughts (e.g. D. Diderot ${ }^{39}$ ) who directly disagreed with Condillac and referring to contemporary commentaries, it is worth noting that the author of the Treatise... is one of the first to strongly emphasize the role of carnality in the process of cognition (long before the contemporary theses on naturalized epistemology, embodied cognition or M. Merleau-Ponty's proposals). Consequences resulting from Condillac's thought and unintentional theoretical problems make the question of subjective activity, or even subtle "slipping" of his position into idealism, problematic for the defenders of radical sensationism, but at the same time extremely inspiring for the researchers who distance themselves from extreme positions.

\section{Bibliography}

Beal Melvin W. 1973. "Condillac as Precursor of Kant". In: Studies on Voltaire and the Eighteenth Century. No. 102. Ed. T. Besterman: 193-229.

Brewer Bill. 1999. Perception and Reason. Oxford: Oxford University Press.

Chudy Wojciech. 1980. "Percepcja a pojęciowanie i sądzenie". Roczniki Filozoficzne 28 (1): 262.

Condillac Etienne B. 1780. La logique, ou Les premiers développements de l'art de penser. Paris.

Condillac Etienne B. 1746. L'Essai sur lorigine des connoissances humaines. Amsterdam.

Condillac Etienne B. 1792. Extrait raisonné du traité des sensations. In: Oeuvres philosophiques de l'abbé de Condillac. Vol. 2. Parma.

Condillac Etienne B. 1754. Traité des sensations. Vol. 1. Londre-Paris.

Falkenstein Lorne. 2005. "Condillac's Paradox". Journal of the History of Philosophy 43 (4): 403-435.

Gregorowicz Marek. 1993. Tematyka sensualistycznego uzasadnienia tożsamości podmiotu ludzkiego i jego odniesień do realności w twórczości Condillaca: dwa studia badawcze. Łódź: Wyd. Uniwersytetu Łódzkiego.

${ }^{39}$ More on the subject by: Stanisław Zapaśnik, Filozofia a kultura Francji XVIII wieku (Warszawa: PWN, 1982), 89-94. 
Janeczek Stanisław. 2007. "Przejawy refleksji metafizycznej w filozofii Etienne’a Bennota de Condillaca (1715-1780)”. In: Z dziejów filozoficznej refleksji nad człowiekiem. Księga pamiątkowa ku czci Profesora Jana Czerkawskiego (1939-2007). Ed. P. Gutowski, P. Gut. Lublin: Wyd. KUL.

Lowe Edward J. 2008. "Tropes and Perception". In: Tropes, Universals, and the Philosophy of Mind-Essays at the Boundary of Ontology and Philosophical Psychology. Ed. S. Gozzano, F. Orilia. Heusenstamm: Ontos Verlag.

McDowell John. 1996. Mind and World. With a New Introduction. Cambridge, Mass.: Harvard University Press.

McNiven Hine Ellen. 1979. A Critical Study of Condillac's Traite des Systems. Hague: Martinus Nijhoff Publishers.

Nichols Ryan. 2007. Thomas Reid's Theory of Perception. Oxford: Oxford University Press.

O'Neal John C. 1996. The Authority of Experience. Sensationist Theory in the French Enlightenment. University Park: Penn. State University Press.

Roos Suzanne. 1999. "Consciousness and the Linguistic in Condillac". MLN 114 (4): 680.

Sellars Wilfrid. 1956. "Empiricism and the Philosophy of Mind". In: Minnesota Studies in the Philosophy of Science. Vol. I. Minneapolis: University of Minnesota Press.

Stam James H. 1980. “Condillac's Epistemolinguistic Question”. In: Psychology of Language and Thought. Essays on the Theory and History of Psycholinguistics. Ed. R. W. Rieber. New York: Plenum Press.

Thiel Udo. 2015. "Self and Sensibility: From Locke to Condillac and Rousseau". Intellectual History Review 25 (3): 260.

Wojciechowska Wanda. 1964. "Sensualizm Condillaca". In: Szkice filozoficzne: Romanowi Ingardenowi w darze. Ed. Z. Żarnecka. Kraków: PWN.

Zapaśnik Stanisław. 1982. Filozofia a kultura Francji XVIII wieku. Warszawa: PWN.

\section{Abstract}

The aim of this article is to consider possible problems that might occur while connecting three problems of sensationism: a) source of sense knowledge; b) perceptual processes; c) real and empirical correlate of our knowledge. The juxtaposition of these three elements in Condillac's thought leads to posing a question about the nature of perceptual content given in perception. The author of the thesis claims that Condillac's standpoint - in spite of his declarations - contains certain proto-conceptual activity which functions simultaneously to our ability to experience sensations. The consequence of this ascertainment is that Condillac's 
radical sensationism - in the version which is often presented - is very hard to defend. According to the author, Condillac may be considered one of the sources of Kant's thought and implied as a source of the contemporary, analytic philosophy of perception.

Keywords: E. B. Condillac, sensationism, sensations, perceptual content, perceptual consciousness 